\title{
Meta
}

Journal des traducteurs

Translators' Journal

RENER, Frederick M. (1989): Interpretatio: Language and

Translation from Cicero to Tytler, Approaches to Translation

Studies, 8, Amsterdam and Atlanta, Rodopi, 367 p.

\section{Brenda Hosington}

Volume 38, numéro 1, mars 1993

La traduction et l'interprétation dans le nord du Canada

Translation and Interpretation in Northen Canada

URI : https://id.erudit.org/iderudit/003136ar

DOI : https://doi.org/10.7202/003136ar

Aller au sommaire du numéro

Éditeur(s)

Les Presses de l'Université de Montréal

ISSN

0026-0452 (imprimé)

1492-1421 (numérique)

Découvrir la revue

Citer ce compte rendu

Hosington, B. (1993). Compte rendu de [RENER, Frederick M. (1989):

Interpretatio: Language and Translation from Cicero to Tytler, Approaches to

Translation Studies, 8, Amsterdam and Atlanta, Rodopi, 367 p.] Meta, 38(1),

127-128. https://doi.org/10.7202/003136ar d'utilisation que vous pouvez consulter en ligne.

https://apropos.erudit.org/fr/usagers/politique-dutilisation/ 
RENER, Frederick M. (1989): Interpretatio: Language and Translation from Cicero to Tytler, Approaches to Translation Studies, 8, Amsterdam and Atlanta, Rodopi, 367 p.

The stated purpose of Frederick M. Rener's Interpretatio: Language and Translation from Cicero to Tytler is to explore a new path which will lead to a clearer understanding of the theory and practice of translation in Western Europe from Classical Antiquity to the end of the eighteenth century. To this end the author employs what he calls "innovative means": 1) a "panoramic view," unlike all previous "narrow" ones, of a continuous and shared theory of language and communication and belief in the hermeneutic nature of translation, the interpretatio of the book's title; 2) a "panoramic approach" in terms of subject matter, that is, a presentation of the whole process of translation as described in a variety of manuals, treatises and related materials drawn from all over Western Europe. According to Rener, no previous author has offered such vistas and "no study is known which seemed to approach this particular subject [translation] from the 'linguistic' point of view" (p. 10). This rather surprising statement accounts perhaps for the total omission of George Steiner's After Babel, the cursory dismissal of Kelly's The True Interpeter (which on page 1 is called The True Translator), and the brief, albeit severe, criticism of Norton's Ideology and Language of Translation in Renaissance France. Other translation scholars' failings, Rener claims, can be imputed to their inadequate understanding of the terminology used by Classical and later authors which they anachronistically translate into present-day jargon. Strong accusations indeed! Despite his claim that he will not descend into the arena of polemic by discussing offending authors and their divergent opinions, Rener does of course continuously allude to them, but anonymously. More's the pity for the reader, tantalizingly confronted over and over again 
with woolly-sounding phrases like "many scholars say" and "most scholars hold," which always arouse one's suspicions. This, however, is a minor criticism. Does Rener, in fact, really deliver what he rather ambitiously promises, namely a new understanding of translation theory and practice from Cicero to Tytler reached by innovative means?

Interpretatio presents a coherent, well-organised and generally accurate history of grammar and rhetoric down to the late eighteenth century. Although nothing in its pages will be startlingly new to those who work in the fields of rhetoric or language theory, its description and explanation of grammar and rhetoric (Parts 1A and 2A) will be very useful to translation students. And it is toward them, after all, that the book is primarily directed. The work is certainly "panoramic" in that it assembles the ideas of authors from Aristotle to von Humbold. Many of them are known to translation students only by name: Leonardi Bruni, Sebastiano, Lawrence Humphrey, for example. Rener, however, misses a golden opportunity to right this by deciding not to translate any quotations. Since many readers will not share his knowledge of Latin, or even perhaps German, this is a big mistake. Rener's "panoramic" lense does sometimes shift a little out of focus. The medieval period, for example, is not well handled. He takes Amos' views (Early Theories of Translation) on English medieval translators, now 70 years old, for granted, overlooking all the recent work done in the field. The Toledo translators are ignored, despite much recent research that throws new light on their prefaces, introductions and prologues. Nor does the Tudor period fare better. Rener is content to use Jones' 1953 Triumph of the English Language for many of his claims, rather than using primary sources and more up-to-date research. In geographical terms, Rener's emphasis falls heavily on humanist Italy, and on France, England and Germany. Nevertheless, the array of sources analysed is impressive and the number of insights afforded of hitherto unavailable authors is valuable.

My main criticism is reserved for another, more central aspect of the work. Rener promises to bring us to a "clearer understanding of the theory and practice of translation." But where is the "practice" in his book? The hermeneutical function of translation cannot be adequately studied without examples of how translation theory is put into practice. As Shakespeare says on more than one occasion, "words are not deeds." In this book, no attention is paid to the "deeds" and precious little to the authors of them: 10 pages out of 364 to be exact. More serious still, Rener never comes to grips with what is meant by the term interpretatio. Although he says, quite rightly, that "the role of interpretatio extends further than the mere attainment of clarity of the text" (p. 329), he minimizes the importance of form and style, even in literary translation: "literary translation is primarily interested in the thought of the original" and "is based on mediation and explanation" (p. 299). Yet surely the form, the verbal aspects, the style are also "mediated" by the translator? They too are part of interpretatio, for in literary translation par excellence, form and content are indissociable. Rener's book, then, disappointingly fails to deliver either a complete and new understanding of the theory and practice of translation, or a full and satisfying definition of interpretatio. It remains a useful history of language theory and rhetoric for students of translation and proves, once more, that these two disciplines are strongly linked to the translation process.

BRENDA HOSINGTON 